\title{
Microbialites at Gusev Crater, Mars.
}

\author{
Giorgio Bianciardi ${ }^{1,2 *}$, Vincenzo Rizzo ${ }^{2}$, Maria Eugenia Farias ${ }^{3}$ and Nicola Cantasano ${ }^{4}$ \\ ${ }^{1}$ Department of Medical Biotechnologies, University of Siena, Siena, Italy \\ ${ }^{2}$ National Research Council-retired, Via Repaci 22, Rende, Cosenza, Italy \\ ${ }^{3}$ Laboratorio de Investigaciones Microbiológicas de Lagunas Andinas (LIMLA), Planta Piloto de Procesos Industriales Microbiológicos (PROIMI), CCT, CONICET, \\ Tucumán, Argentina
}

${ }^{4}$ National Research Council, Institute for Agricultural and Forest Systems in the Mediterranean, Rende Research Unit, Cosenza, Italy

*Corresponding author: Giorgio Bianciardi, Department of Medical Biotechnologies, University of Siena, Siena, Italy, Tel: +39 348 2650891; E-mail: giorgio.bianciardi@unisi.it

Rec date: September 28, 2015; Acc date: October 31, 2015; Pub date: November 3, 2015

Copyright: (c) 2015 Giorgio Bianciardi, et al. This is an open-access article distributed under the terms of the Creative Commons Attribution License, which permits unrestricted use, distribution, and reproduction in any medium, provided the original author and source are credited.

\begin{abstract}
The Mars Exploration Rover Spirit investigated plains at Gusev crater, where sedimentary rocks are present. The Spirit rover's Athena morphological investigation shows microstructures organized in intertwined filaments of microspherules: a texture we have also found on samples of terrestrial stromatolites and other microbialites. We performed a quantitative image analysis to compare 45 microbialites samplings with 50 rover's ones (approximately 25,000/20,000 microstructures). Contours were extracted and morphometric indexes obtained: geometric and algorithmic complexities, entropy, tortuosity, minimum and maximum diameters. Terrestrial and Martian textures resulted multifractals, while terrestrial abiogenic minerals showed a simple fractal structure. Mean values and confidence intervals from the Martian images overlapped perfectly with those from terrestrial samples. The probability of this occurring by chance was less than $1 / 2^{8}, p<0.004$. Our work show the presumptive evidence of microbialites in the Martian outcroppings explored by "Spirit", confirming our previous results concerning the Martian outcroppings explored by Opportunity at Meridiani Planum: unicellular life was widespread on the ancient Mars.
\end{abstract}

Keywords: Spirit mars exploration rover; Stromatolites; Microbialites; Fractal analysis; Life on Mars

\section{Introduction}

Rover Spirit touched down the volcanic plains of Gusev Crater on 4 January 2004, for almost ten years it has runned on the Martian surface. From the landing site to "Pot of Gold" site (on sol 200 about), extensive/destroyed volcanic outcroppings, often covered by weathering coatings and/or floating on eolic sands, as crater ejecta were found. The Rover then reached the inner basin of Columbia Hills, the images showed here layered sequences, containing sulfate and other soluble elements, due to ancient large process of aqueous alteration [1-3]. At Home Plate, where are the most evident geologic feature investigated in the Inner Basin, these layered sequences appeared formed by erosion of basaltic rocks and pyroclastic rocks, deposited as alluvial fans and/or as eolian sand sheets [4-7]. In effect, ancient volcanic ash, known as "tephra", and hydrothermal deposits created in a nearby volcanic eruption, initially covered much of the Columbia Hills and the surrounding area [8], and then was covered by deposit of a cold lake [9]. The wind and weathering processes eroded most of that deposit, also carrying away much of the evidence for the ancient lake: an environment where to search for life could be interesting.

Stromatolites/microbialites are a frequently named target of lifedetection missions on Mars [10-13]. Stromatolites/microbialites are an organization of primitive cyanobacteria, analogous to coral reefs that grow/grew in vast colonies. Fossil stromatolites, as well other microbialites, can be identified through their macro-meso-micro- characteristic structures that result from the growth patterns of their constituent bacteria [14-17].

Rizzo observed by a qualitative visual inspection that images of Martian outcroppings (selected frames from images obtained by Opportunity and Spirit rovers) presented features resembling terrestrial stromatolites/microbialites [18-20]. Recently, we performed a fractal morphometric quantitative analysis of the Martian outcroppings explored by the Rover Opportunity revealing evidences of the presence of microbialites at Meridiani Planum [21]. In order to search for possible signature of microbialites in other Martian regions, we have performed a morphometric analysis of the Martian outcroppings shot by the Athena facility aboard of the Rover Spirit, comparing fractal morphometric indexes of the microtextures evidenced in the Martian outcropping with the ones of terrestrial microbialites.

\section{Materials and Methods}

All the Martian images elaborated in this work are referred to float or weathered rocks, somewhere ejected by meteoric impact.

\section{Samples}

This study undertakes a systematic analysis of black and white Microscopic Images (MI) obtained by Athena (Figure 1), a camera mounted on the NASA Mars Exploration Rovers (MER) "Spirit", selecting all the images that presented microspherules and filaments of microspherules (V.R.). The field of view of Athena is $1024^{\star} 1024$ pixels in size and its optics provide a square frame of $32 \mathrm{~mm}$ of-field sampling at the working distance of about $63 \mathrm{~mm}$ from the front of the 
Page 2 of 8

lens barrel to the object plane, consequently having a resolution of about 30 micrometers [22]. In particular, 20 selected MI images obtained by the rover Spirit have been chosen and 50 samplings obtained (Figures 1 and 2), approximately corresponding to the presence of 20,000 microspherules/intertwined filaments of microspherules.

These cuttings having dimensions of about $1 / 4$ of the original images $(8-10 \mathrm{~mm})$ were subjected to a slight contrast increase (Microsoft Publisher software) for an optimal vision of the microstructures. The studied cuttings were related to polished surfaces by MER's Rock Abrasion Tool (RAT) or to exposed surfaces of the Martian outcroppings.

As regards terrestrial stromatolites, unambiguously determined as biogenic, 20 quoted images and 45 samplings were obtained (Figure 3) from the WEB (from which one sample of terrestrial stromatolite photographed by Athena and one from cultured cyanobacteria, see Figure 2 or photographed at the Regional Museum of Natural Sciences, Turin, approximately corresponding to 25,000 microspherules/ intertwined filaments of microspherules (Figure 2). They have been acquired and magnified in order to obtain the same dimensional scale ( $\pm 10 \%)$, resolution and acutance of the Athena imagery (V. R.). They were analyzed using the same procedures of the Martian images.

\section{Image analysis}

The contours present in the terrestrial and Martian images (biogenic stromatolites and selected images shot by Spirit) were automatically extracted from the images and converted to single pixel outlines by a canny-edge filter (Digital Image Magnifier software by Strikos Nikolaos: http://www.softoxi.com/digital-image-magnifier.html), (fixed sigma and low threshold values, equals to 0.9 and 12 , respectively) (Figure 4).

The obtained textures were characterized by analyzing their geometrical complexity, entropy (Information Dimension), algorithmic complexity (L-Z, randomness) and tortuosity (Dmin). Minimum and maximum diameters of the microspherules were also measured.

\section{Geometrical Complexity, D0}

To evaluate the geometrical complexity of the patterns, the local fractal dimension was measured using the box-counting algorithm. Resulting our texture multifractals, as identified by the two straight lines on the log-log plot (Figure 5), the algorithm was applied for the two regions: $200-10$ pixels $=2 \mathrm{~mm}-0.1 \mathrm{~mm}$ and $10-5$ pixels $=0.1$ $\mathrm{mm}-0.05 \mathrm{~mm}$. Briefly, each image was covered by a net of $\mathrm{L}$ square boxes and the number of boxes containing any part of the outline $\mathrm{Nb}(\mathrm{L})$ was counted. The slope of the $\log -\log$ plot of $\mathrm{Nb}(\mathrm{L})$ vs. $1 / \mathrm{L}$ represented the fractal dimension of the distribution (Figure 5) [23]. The existence of log-log straight lines $(\mathrm{p}<0.001)$ justified the use of the fractal analysis, applied here as a tool to obtain the morphometric indexes. The method was validated by measuring computer-generated Euclidean and fractal shapes of known fractal dimensions (Circumference $=-0.7 \%$; Square $=+0.4 \%$; Triadic Koch island $=-0.9 \%$; Sierpinski’s Triangle $=-1.5 \%)$.

\section{Entropy (Information Dimension, D1)}

To evaluate the information (entropy) present in the patterns, information dimension, D1, a robust estimate from a finite amount of data that gives the probability of finding a point in the image, was calculated. The set was covered with boxes of linear size, d, from 200 to 10 pixels and from 10 to 5 pixels as above, keeping track of the mass, $\mathrm{mi}$ (the amount of pixels) in each box, and calculated the information entropy I (d) from the summation of the number of points in the i-th box divided by the total number of points in the set multiplied for its logarithm [24]. The slope of the log-log plot of Information entropy vs. $1 /$ box side length represented the information dimension of the distribution. The method was validated by measuring computer generated Euclidean and fractal shapes of known information dimensions. The existence of $\log$-log straight lines $(\mathrm{p}<0.001)$ justified the use of the fractal analysis, applied here as a tool to obtain the morphometric indexes.

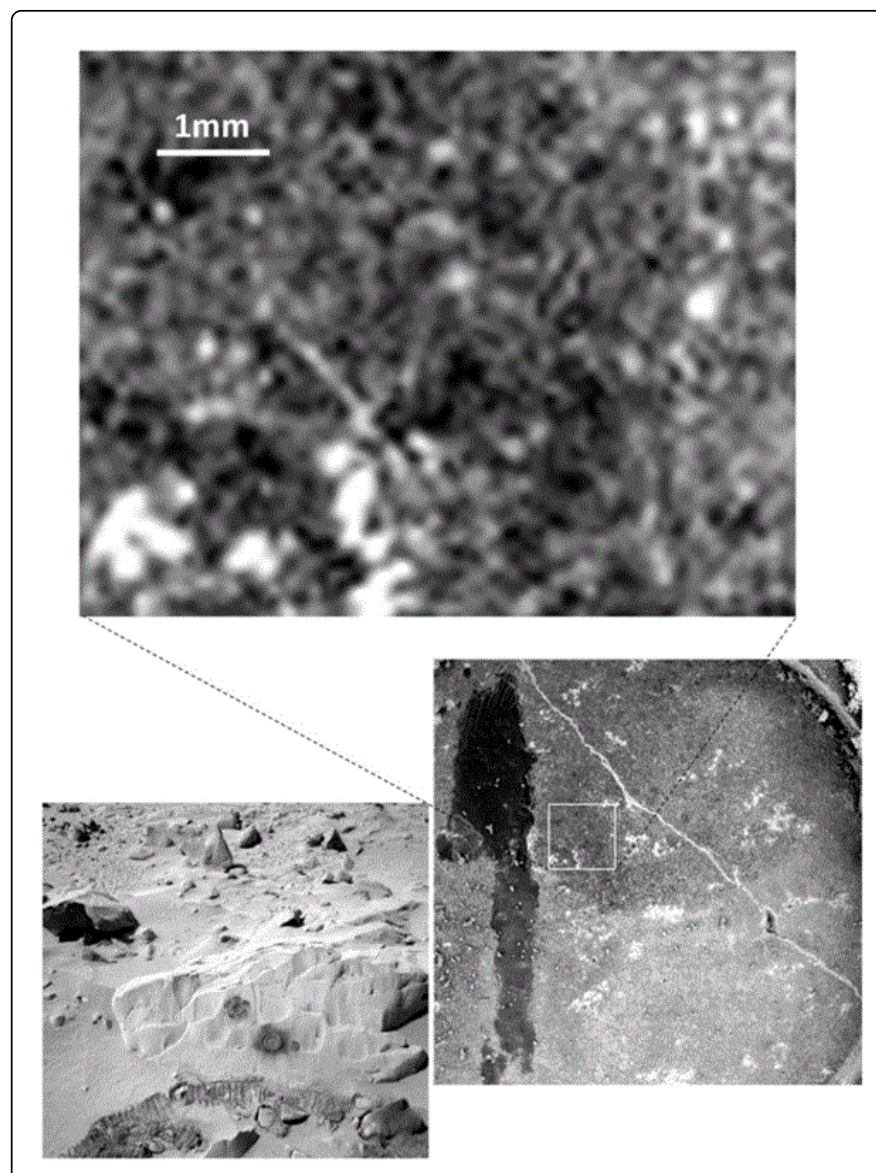

Figure 1: Bottom>Top. A Martian landscape photographed by Spirit, abraded sample by Spirit, its magnification: some microstructures (microspherules and intertwined filaments of microspherules) are revealed. 
Citation: Giorgio Bianciardi, Vincenzo Rizzo, Maria Eugenia Farias, Nicola Cantasano (2015) Microbialites at Gusev Crater, Mars.. Astrobiol

\begin{tabular}{|c|c|c|c|c|c|c|c|}
\hline \multicolumn{4}{|c|}{ MARS (Rover I Microscopic Imagery selection) } & \multicolumn{4}{|c|}{ EARTM (fossil and living microbialites) } \\
\hline 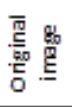 & $\frac{\frac{g}{2}}{\frac{2}{E}}$ & sol & source & 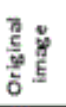 & 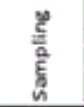 & Stromatolites & Source \\
\hline 1 & 1 & 60 & 2M131690279EFF1155P 2039M2M1 & 1 & 1.5 & $\begin{array}{c}\text { Recent stromat. (a), Lagoa } \\
\text { Salzada, Brazil (Srivastava, } \\
\text { 1999; fie. 5) }\end{array}$ & 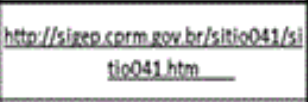 \\
\hline 2 & $2-4$ & 32 & 2M133648332EFF2232P 2979M2M1 & 2 & $6 \_8$ & \begin{tabular}{|c|} 
Living microbialite, La Brava, \\
Salar de Atacama, chile
\end{tabular} & 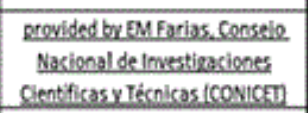 \\
\hline 3 & 5 & 35 & ZM133914740EFF2232P 2979M2M1 & \multirow{2}{*}{3} & \multirow{2}{*}{9,12} & \multirow{2}{*}{$\begin{array}{l}\text { Proterosoic columnar } \\
\text { stromatolite, Mauritania } \\
\text { (Borque collection) }\end{array}$} & 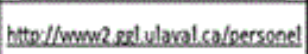 \\
\hline \multirow{2}{*}{4} & \multirow{2}{*}{6} & \multirow{2}{*}{214} & \multirow{2}{*}{ ZM145365403EFF 25000 2959M2M1 } & & & & borcue/s4/stromatolites ansiens \\
\hline & & & & \multirow{2}{*}{4} & \multirow{2}{*}{13} & \multirow{2}{*}{\begin{tabular}{|}
$\begin{array}{c}\text { Proterozoic stromatolite, South } \\
\text { (Schooff, } \\
\text { Africa } \\
2006 ; \text { fig 1, c) } \\
\end{array}$ \\
\end{tabular}} & abs belffrebonino/html \\
\hline 5 & 9 & 223 & 2M14660963 & & & & ematoliti intont \\
\hline 6 & 10 & 259 & ZM149359510EFF8800P 2960M2M1 & 5 & 14 & \begin{tabular}{|c|}
$\begin{array}{c}\text { Devonian columnar } \\
\text { stromatolite, Australia (Borque } \\
\text { coll.) }\end{array}$ \\
\end{tabular} & 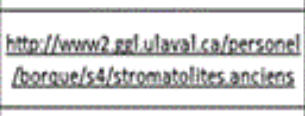 \\
\hline 7 & 11 & 299 & 2M152912555EFF89AIP 2957M2M1 & 6 & 15 & $\begin{array}{c}\text { Stromatolite shots on Earth by } \\
\text { tathena }\end{array}$ & hetol/marsrover nasagov \\
\hline 8 & $12-13$ & 333 & 2M155931811EFF9946P 2936M2M1 & 7 & 16 & $\begin{array}{c}\text { Proterozoic stromat, Collenia } \\
\text { type, Michizan, USA (University } \\
\text { museum) }\end{array}$ & 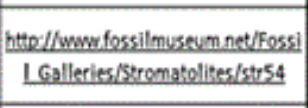 \\
\hline 9 & 14 & 334 & ZM156024338EFF9946P 2957M2M1 & 8. & 17 & \begin{tabular}{|l|} 
Silurian stromat, Gotland, \\
Sumeden (Nose et al_2005: fig
\end{tabular} & tiencedirest.com/ssien \\
\hline & & & & 管 & 20 & 12 ) & ce/article \\
\hline 10 & 16 - 17 & 354 & 2M157793588EFFA269P2977MZM1 & & & Proterozoic stromat., & \\
\hline 11 & 18 & 358 & 2M158147821EFFA269P2977MZ2M1 & 9 & 18 & $\begin{array}{l}\text { Earaheedia type, Wiluns, } \\
\text { Austr. (Bonino colli). }\end{array}$ & ematolitititml \\
\hline 12 & $19+20$ & 372 & 2M159395697EFFA2HPP 2957M2M1 & 10 & 19 & $\begin{array}{l}\text { Proterozoic stromst, BlF type, } \\
\text { Pilbara, Austr. (Bonino colli) }\end{array}$ & $\begin{array}{c}\text { wowikevobs. be/fr/ebonino/htm 1/str } \\
\text { omatoliti.itoml }\end{array}$ \\
\hline 13 & 21 & 373 & 2M159478547EFFA2HPP 2957M2M1 & 11 & 20 & \begin{tabular}{|c|}
$\begin{array}{c}\text { Paleoproterozoic stromat, } \\
\text { Cochabamba, Bolivia (Bonino } \\
\text { coll.) }\end{array}$ \\
\end{tabular} & $\begin{array}{c}\text { www kevobs be/fr/ebonino/htmil/str } \\
\text { onatolitihtoml }\end{array}$ \\
\hline 10 & $22 \_26$ & 374 & 2M159567193EFFA2HPP 2957M2M1 & 12 & 21 & $\begin{array}{c}\text { Paleoproterozoic stromat, } \\
\text { Collenia type, Minnesota, USA } \\
\text { (Bonino coll.) }\end{array}$ & 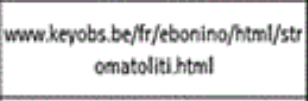 \\
\hline 11 & $2 z_{-} 31$ & 395 & 2M160631672EFFA2K1P2957M2M1 & 13 & 22 & $\begin{array}{c}\text { Paleoproterozoic stromat, } \\
\text { Cochabsmba, Bolivia (Bonino } \\
\text { coll.) }\end{array}$ & $\begin{array}{l}\text { wwwikerobs be/ff/ebonino/html/str } \\
\text { onatolitihtml }\end{array}$ \\
\hline 12 & 32 & 511 & 2M171727638EFFANCP2977M2M1 & 14 & 32 & Cretaceous stromat, & hattp//www lowestone.com/acatalo \\
\hline 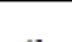 & 3 & $\operatorname{sen}$ & & 14 & 20 & Pocalithus typ & I/Fossils-for-salehtnel \\
\hline 13 & 33 & 675 & 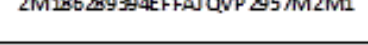 & & & Middle Devonian stromat, & \\
\hline 14 & 37 & 698 & 2M187443970EFFANXYP2956MZM1 & 15 & $24 \_26$ & $\begin{array}{l}\text { Orcadian Lake, Scotland } \\
\text { (University Museum) }\end{array}$ & ssilis/Stromatolitehtm \\
\hline 15 & $38-40$ & 754 & ZM19331551EFFAOAOP2956MZZ1 & 16 & 27 & $\begin{array}{l}\text { Archean stromat, Wyomine } \\
\text { USA (EDCOPE) }\end{array}$ & $\begin{array}{c}\text { hatto//humw fossilmillicom/EDCOPE } \\
\text { Enterorises/stromatolite }\end{array}$ \\
\hline 16 & 41 & $m 0$ & 2M194720101FFFAP BCP 295 GM2M1 & 17 & $28 \_30$ & $\begin{array}{c}\begin{array}{c}\text { Precambrian stromat, BuF type, } \\
\text { Minnesota, USA (lames St. John } \\
\text { coll.) }\end{array} \\
\end{array}$ & $\begin{array}{l}\text { hatto//homw newarkesueduffaculty } \\
\text { staffleersons//istiohn/Decuments }\end{array}$ \\
\hline 17 & 44 & 1368 & 2M247814647EFFAW CCP 2976M2M1 & 18 & 31 35 & \begin{tabular}{|c|}
$\begin{array}{c}\text { Precambrian stromat, } \\
\text { Chocabamba,Bolivia, Sannple } \\
\text { R2162. }\end{array}$ \\
\end{tabular} & $\begin{array}{l}\text { Photos shot at Regional Museum of } \\
\text { Natural Sciences, Turin. }\end{array}$ \\
\hline 13 & $45-48$ & 1434 & 2M253668740EFFAX05P2956MRM1 & 19 & 36.40 & \begin{tabular}{|c|} 
Precambrian stromat, \\
dolomitic, South Africa. Sample \\
3713.
\end{tabular} & $\begin{array}{l}\text { Photos shot at Regional Museum of } \\
\text { Natural Sciences, Turin. }\end{array}$ \\
\hline 19 & 49 & 1452 & 2M255266694EFFAX16P297 6M2M1 & & & Middle Cambrian Stromat, & \\
\hline 20 & 50 & 1967 & ZM300990702EFFB1E5 2936MZM3 & 20 & $411_{-} 45$ & $\begin{array}{c}\text { Xinshan, China. Sample } \\
\text { GEO5216. }\end{array}$ & Natural Sciences, Turin. \\
\hline
\end{tabular}

Figure 2: List of sampled images: Martian samples photographed by Spirit and terrestrial (biogenic) stromatolites selected by web sites or photographed at the Regional Museum of Natural Sciences, Turin. 
Citation: Giorgio Bianciardi, Vincenzo Rizzo, Maria Eugenia Farias, Nicola Cantasano (2015) Microbialites at Gusev Crater, Mars.. Astrobiol Outreach 3: 143. doi:10.4172/2332-2519.1000143

Page 4 of 8
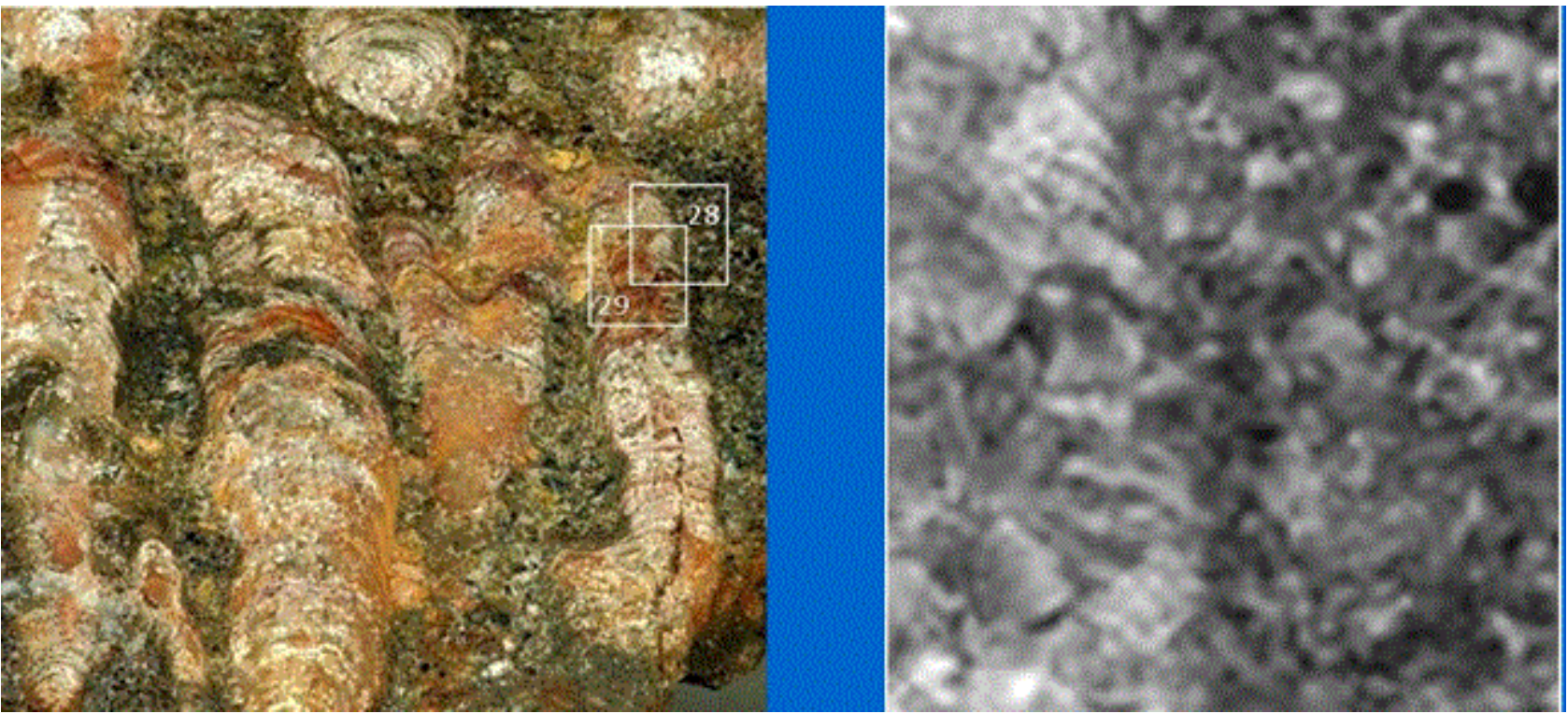

Figure 3: Sample \#28 (left) from a Precambrian stromatolite (Banded Iron Formation type, Minnesota, USA, James St. John Collection), enlarged (right) in order to obtain the same magnification resolution and acutance than the Athena enlarged images (Figure 1).Microspherules and intertwined filaments of microspherules are revealed. This stromatolite lived billion years ago in an anoxic Earth (as Mars today).

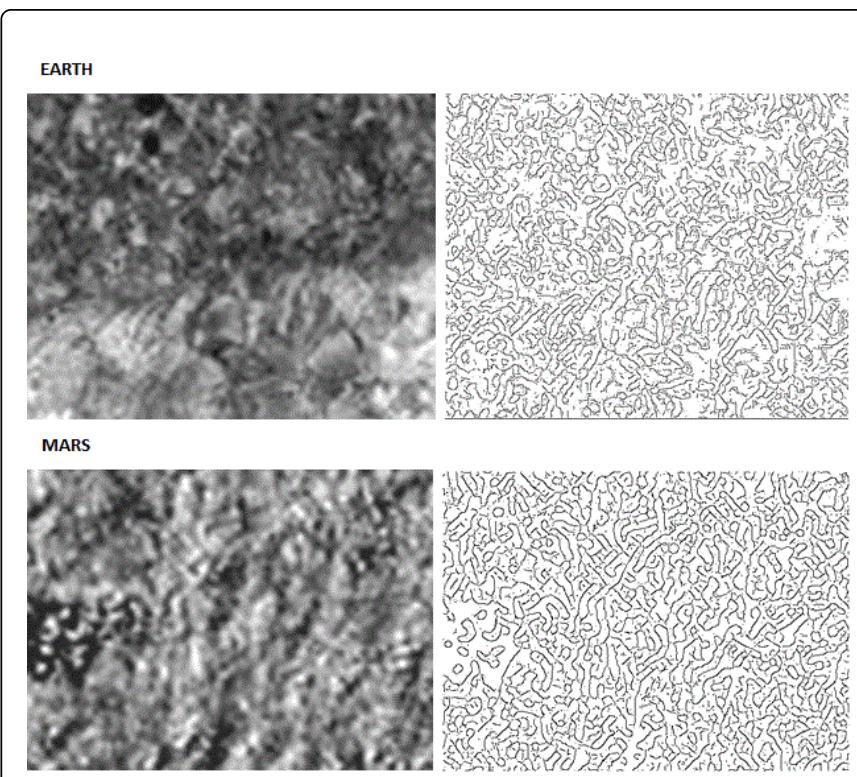

Figure 4: Terrestrial sample of a (biogenic) stromatolite (sample 28, the same of figure 3, top, left), its automatically extracted contours (top, right); Martian sample photographed by Spirit Rover (sol 228, figure 2) and its automatically extracted contours (below, right). Magnification is the same $( \pm 10 \%)$.

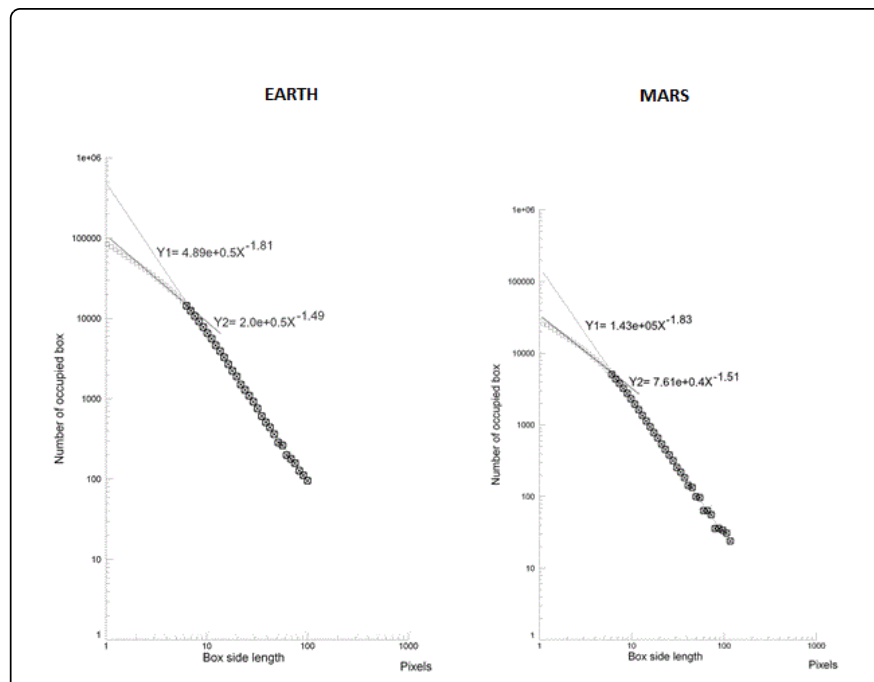

Figure 5: Left, log-log plot of a terrestrial sample of a (biogenic) stromatolite, and, right, of a Martian sample photographed by the Spirit Rover. Magnification is the same. Both the samples are multifractals, as evidenced by the presence of two straight lines (from 200 to 10 pixels, from 10 to 5 pixels) with different slopes. Please, note also the remarkable similarity of their critical exponents (geometrical complexity or local fractal dimensions by box-counting).

\section{Algorithmic complexity (“randomness", L-Z)}

To determine the algorithmic complexity ("randomness") of the patterns, relative Lempel-Ziv, L-Z, values were calculated according to 
the Kaspar and Schuster algorithm [25] using the Chaos Data Analyzer version 2.1 software package (CDA; Pro, Academic Software Library, North Carolina State University, USA). Briefly, patterns of the original image were transformed into 16.732 points containing one dimensional vector, where each datum point was converted into a single binary digit according to whether the design is touched $(=1)$ or not $(=0)$. Relative $\mathrm{L}-\mathrm{Z}$ values are close to 0 for a deterministic equation, close to 1 for totally destructured random phenomena.

\section{Tortuosity (Dmin)}

Tortuosity, or the fractal dimension of the minimum path, Dmin, was computed for each cluster present in the image from the power law $\mathrm{Ic}=\mathrm{r}^{\mathrm{Dmin}}$, where Dmin is the exponent that governs the dependence of the minimum path length between two points (Ic) on the Pythagorean distance $r$ between them in a fractal random material. To obtain Dmin, the maximum diameter and the half perimeter of the microstructures present in the textures were measured using an automated procedure (Image Pro Plus software, Media Cybernetics, USA). For each image 100-500 microstructures were measured. The slope of the log-log plot (maximum diameter vs. perimeter) represented Dmin. The existence of a log-log straight line $(\mathrm{p}<0.001)$ justified the use of the fractal analysis in order to obtain the morphometric index. The method was validated with the original one by Hermann and Stanley [26] with a maximum shift of $\pm 3 \%$.

Geometrical Complexity and Information Dimension were calculated using the Benoit 1.3 software, (TruSoft Int'l Inc: http:// trusoft-international.com/benoit.html). Algorithmic complexity and Dmin were calculated using a software written by us. All this four methods are routinely performed by one of us in biomedical works [26-31]. Minimum and maximum diameters of the microspherules (Earth and Mars) were automatically measured by Image Pro Plus software (Media Cybernetics, USA).

\section{Statistical analysis}

Mean intra-and inter-observer coefficients varied $<2.0 \%$ and $<3 \%$, respectively. Comparisons between the groups were analyzed by the Mann-Whitney $\mathrm{U}$ test and chi-square test; $\mathrm{t}$-test was applied in order to verify the linearity of the log-log plots.

\section{Results}

In the images photographed by Spirit as well from the images obtained from terrestrial microbialites a continuum pattern of microspherules and intertwined filaments of microspherules, dimensions of about $0.1 \mathrm{~mm}-0.3 \mathrm{~mm}$, are present. Figure 6 show the same microstructures observed at high magnification after Scanning Electron Microscopy.

On Earth, these reports are prevalently referred to the microbialitic environment, where the microspherule, somewhere aggregate in linear arrays, is known as peloids [32-34].

The morphometric analysis reveals that both textures, from microbialites (Earth) and from selected MI images (Mars), present a multifractal aspect, as revealed by the two straight lines in the log-log plot (Figure 5). Two textures are present: the texture as a whole (200-10 pixels, corresponding to $2 \mathrm{~mm}-0.1 \mathrm{~mm}$ ) and the microstructure inside the microspherules and the intertwined filaments of microspherules (10-5 pixels, corresponding to $0.1 \mathrm{~mm}-0.05 \mathrm{~mm}$ ).
Abiogenic pseudostromatolites, as well other abiogenic minerals, reveal always a simple fractal (and not multifractal) textures (Figure 7) $[20,21]$.

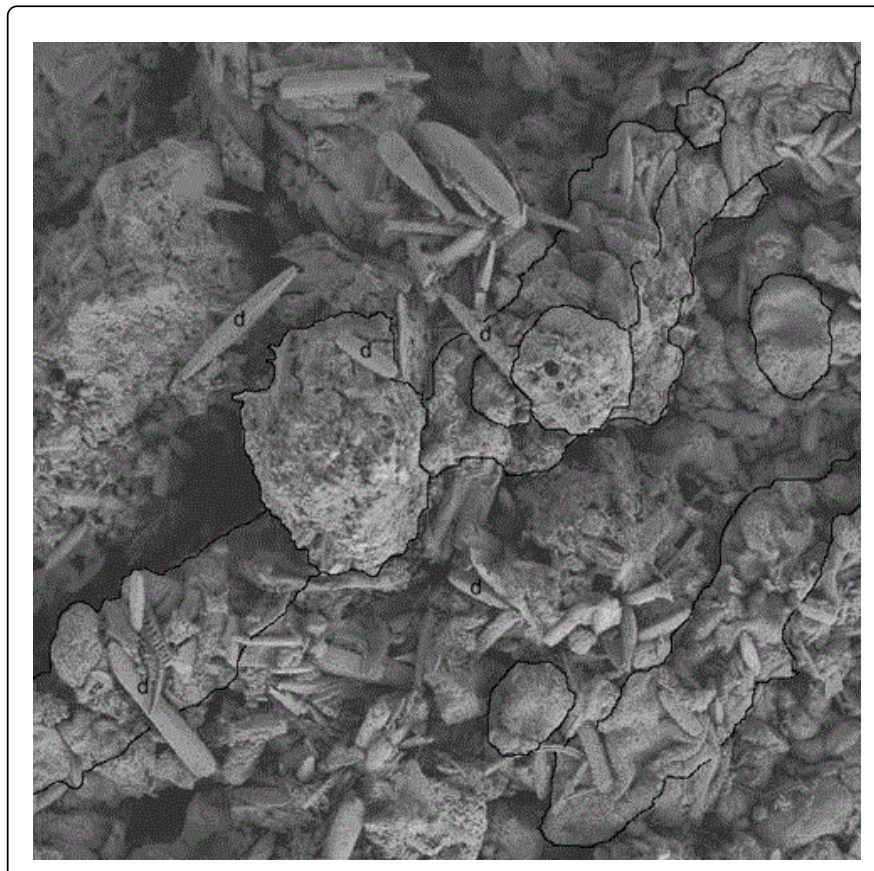

Figure 6: Scanning Electron Images of a living microbialite at La Brava (M.E.F.). The picture highlights occurrence of microspherules and filaments, minerals built by Cyanobacteria; other living forms, diatoms, are present, d, over the microfilaments. X 100.

The morphometric analysis also shows that the Martian and terrestrial textures were extremely similar to each other; the average values and confidence intervals of the eight independent morphometric parameters of the terrestrial and Martian images perfectly overlapped with each other (table 1 ). In these eight separate comparisons, the probability of this occurring by chance is $1 / 2^{8}$ $(\mathrm{p}<0.004)$.

\section{Discussion}

The search of life on Mars is the main motivation behind the different research programs on the Martian surface. Our knowledge on Mars has remarkably increased after the last NASA missions, especially those called Mars Explorer Rover (MER, Opportunity, Spirit and Curiosity rovers) held, from 2004 on the Mars landscape at Meridiani Planum and Gale Crater, respectively. Indeed, the photo reportages realized by the Martian rovers confirmed the presence of water deposits on the surface of Mars [35].

The search on Mars of extraterrestrial microorganisms and, in particular, of cyanobacteria, the main building materials of terrestrial microbialites/stromatolites [36] has been underlined many times. A century of research on stromatolites has revealed diverse fabric and many structures together with a contentious history and various definitions. 

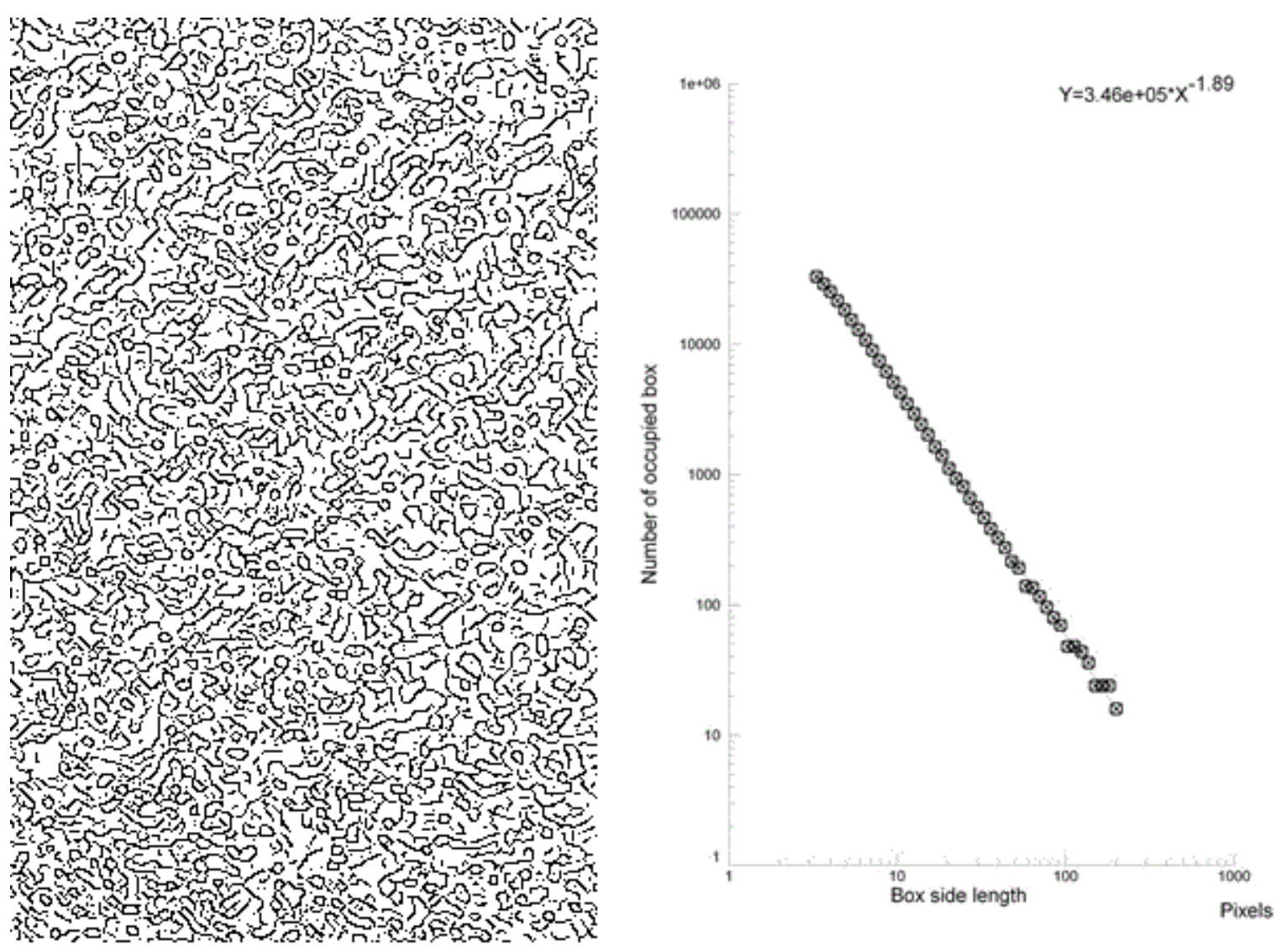

Figure 7: Terrestrial abiogenic microspherules-containing granular sediment (a siltstone), showing microspherules in its automatically extracted contours (left), its log-log plots (right). The log-log plot is fractal (one single straight line from 200 to 3 pixels, corresponding to 2 $\mathrm{mm}-0.03 \mathrm{~mm}$ ) but not multifractals like as the biogenic microbialites (Figure 5).

Besides, most of microbialites/stromatolites are carbonate in composition, but siliceous, phosphatic, iron, manganese and sulphate examples also occur: in recent view, stromatolites may be defined as microbialites, macroscopically layered authigenic microbial sediments, namely organosedimentary rocks [17]. In this frame, the outcroppings on Mars surface at Meridiani Planum (Opportunity Rover) or at Gusev Crater (Spirit Rover) represent an interesting field for microstructure/ textures investigations $[4,37]$.

In this work we analyzed enlarged photographic images, at the same magnifications, resolution and acutance, of stromatolites and of the Martian images obtained with the Athena system of the Spirit Martian Rover. At our range of magnification and resolution is possible to study microstructures in the $1-0.05 \mathrm{~mm}$ size range: a field characterized in the terrestrial microbialites/stromatolites by clotted fabric, tipically formed by widespread micritic clots or lumps, agglutinated and set in an irregular sponge-like network structure or in intertwined turf-like communities [15-17], giving origin to the aspects of microspherules and intertwined filaments of microspherules (see, Figure 6, to look these microstructures at high magnification)

All these structures and aspects are very interesting for astrobiological purposes because they are difficult to explain as abiogenic artifacts. In fact, while the sediment structure follows universal and repetitive laws (revealing in the present work a simple fractal structure, Figure 7, right), the biological structure, within the same environment, at the same meso-microscopic scales, appears to vary depending on the metabolic activity of the living organisms [38-43] (revealing in the present work a multifractal structure, Figure 5 , left).

In this paper, a tangle of microspherule and intertwined filaments of microspherules has been evidenced on the Martian sediments photographed by the Spirit rover: a textural pattern that is also present in living microbialites as well in recent and fossil stromatolites [18-20]. Both the textures, from microbialite images (Earth) or from analyzed MI images (Mars), are multifractals, as revealed by the two straight lines present in the log-log plots (Figure 5). At a quantitative analysis, our objective morphometric approach reveals indexes of geometric and algorithmic complexity, entropy, and tortuosity, minimum and maximum diameters of the microtextures extremely similar among them: average values and confidence intervals of the eight independent fractal parameters between Earth (stromatolites and other microbialites) and Mars samples perfectly overlap. The probability of this occurring by chance is less than $1 / 2^{8}(\mathrm{p}<0.004)$.

We may note that at Spirit location we obtained the same results we have had analyzing sediments photographed by Opportunity Rover at Meridiani Planum [21], a region very far away from Gusev crater. On February 2015, Nora Nofke [44], in a visual inspection of images shot 
Page 7 of 8

by Curiosity Rover (landed in a further region of Mars, at Gale crater)

Evidences of microbialites in the Martian outcroppings are noted signs of the presence of stromatolites in the Martian landscapes. multiplying: unicellular life was widespread on the ancient Mars.

\begin{tabular}{|l|l|l|}
\hline & EARTH/ Mean (SD) & MARS (Spirit location)/ Mean (SD) \\
\hline Geometric Complexity, High scale & $1.82(0.02)$ & $1.81(0.02)$ \\
\hline Geometric Complexity, Low scale & $1.48(0.05)$ & $1.51(0.07)$ \\
\hline Information Entropy, High scale & $1.88(0.01)$ & $1.85(0.02)$ \\
\hline Information Entropy, Low scale & $1.42(0.05)$ & $1.46(0.05)$ \\
\hline Randomness (Lempel-Ziv index) & $0.46(0.05)$ & $0.48(0.04)$ \\
\hline Tortuosity (Dmin) & $0.79(0.03)$ & $0.80(0.03)$ \\
\hline Minimum diameter $(\mathrm{mm})$ & $0.077(0.001)$ & $0.080(0.002)$ \\
\hline Maximum diameter $(\mathrm{mm})$ & $0.2066(0.003)$ & $0.2069(0.004)$ \\
\hline
\end{tabular}

Table 1: Eight different morphometric indexes of microspherule/intertwined filaments of microspherules, mean and standard deviation, were obtained from 45 terrestrial microbialite images and 50 Martian images, corresponding to approximately 25,000/20,000 microstructures analyzed. Note the remarkable similarity of the Earth/Mars indexes: The probability of this occurring by chance is less than $\mathrm{p}<0.004$.

\section{References}

1. Arvidson RE, Squyres SW, Anderson RC, Bell III JF, Blaney D, et al. (2006) Overview of the Spirit Mars Exploration Rover Mission to Gusev Crater: landing site to Backstay Rock in the Columbia Hills. Journal of Geophysical Research 111.

2. Arvidson RE, Ruff SW, Morris RW, Ming DW, Crumpler RS, et al. (2008) Spirit Mars Rover Mission to the Columbia Hills, Gusev Crtaer: Mission overview and selected results from the Cumberland Ridge to Home Plate. Journal of Geophysical Research 113: E12.

3. Ming DW, Mittlefehldt DW, Morris RW, Golden DC, Gellert R, et al. (2006) Geochemical and mineralogical indicators for aqueous processes in the Columbia Hills of Gusev Crater, Mars. Journal of Geophysical Research 111: E02.

4. Grotzinger JP, Milliken RE (2012) The sedimentary rock record of Mars: distribution, origins and global stratigraphy. Sedimentary Geology of Mars 102: 1-48.

5. Ruff SW, Farmer JD, Calvin WM, Herkenhoff KE, Johnson JR, et al. (2011) Characteristics, distribution, origin, and significance of opaline silica observed by the Spirit Rover in Gusev Crater, Mars. Journal of Geophysical Research 116: E07.

6. Sullivan R, Arvidson R, Bell III JF, Gellert R, Golombek M, et al. (2008) Wind-driven particle mobility on Mars: Insights from Mars Exploration Rover observations at "El Dorado" and surroundings at Gusev Crater. Journal of Geophysical Research. 113: E06.

7. Squyres SW, Aharonson O, Clark BC, Cohen BA, Crunpler L, et al. (2007) Pyroclastic activity at Home Plate in Gusev Crater, Mars. Science 316: 738-742.

8. Morris RV, Ruff SW, Gellert R, Ming DW, Arvidson RE, et al. (2010) Identification of Carbonate-Rich Outcrops on Mars by the Spirit Rover. Science 329: 421-424.

9. Ruff SW, Niles PB, Alfano F, Clark AB (2014) Evidence for a Noachianaged ephemeral lake in Gusev Crater, Mars. Geology 42: 359-362.

10. Arrhenius G, Mojzsis SJ (1996) Extraterrestrial life - life on Mars, then and now. Current Biology 6: 1213-1216.

11. McKay, C.P. (2004). Wet and cold thick atmosphere on early Mars. J. Phys. France 121, 283-288.

12. Jepsen SM, Priscu JC, Grimm RE, Bullock MA (2007) The potential for Lithoautotrophic life on Mars: application to shallow interfacial Water Environments. Astrobiology 7: 342-354.
13. Clarke JD, Stocker CR (2013) Searching for stromatolites: the 3.4 ga Strelley Pool Formation (Pilbara region, Western Australia) as a Mars analogue. Icarus 224: 413-423.

14. Riding R (2000) Microbial carbonates: the geological record of calcified bacterial-algal mats and biofilms. Sedimentology 47: 179-214.

15. Riding R (2006) Microbial carbonates: processes and products in time and space. In 17th International Sedimentological Congress, Fukuoka, Japan.

16. Riding R (2008) Abiogenic. Microbial and hybrid authigenic carbonate crusts: components of Precambrian stromatolites. Geologica Croatica 61: 73-103.

17. Riding $\mathrm{R}$ (2011) The nature of Stromatolites: 3,500 Million years of History and a Century of Research. In Advances in Stromatolite Geobiology, Reitner J, et al. (Eds) Lecture Notes in Earth Sciences 131: 29-74.

18. Rizzo V, Cantasano N (2009) Possibile organosedimentary structures on Mars. International Journal of Astrobiology 8: 267-280.

19. Rizzo V, Cantasano N (2011) Textures on Mars: evidences of a biogenic environment. In Memorie della Società Astronomica Italiana 82: 348-357.

20. Rizzo V, Farias ME, Cantasano N, Billi D, Contreras M, et al. (2015) Structures/textures of living/fossil microbialites and their implications in biogenicity, an astrobiological point of view. Applied Cell Biology 4: 65-82.

21. Bianciardi G, Rizzo V, Cantasano N (2014) Opportunity Rover's image analysis: Microbialites on Mars? IJASS 15: 419-433.

22. Squyres SW, Arvidson RE, Bell JF, Brückner J, Cabrol NA, et al. (2004) The Opportunity Rover's Athena Science Investigation at Meridiani Planum, Mars. Science 306: 1698-1703.

23. Falkoner K (1990) Fractal Geometry. Mathematical Foundations and Applications. (2ndedn) John Wiley \& Sons Ltd UK.

24. Pitsianis N, Bleris GL, Argyrakis P (1989) Information dimension in fractal structures. Phys Rev B 39: 7097-7100.

25. Kaspar F, Schuster HG (1987) Easily calculable measure for the complexity of spatiote1mporal patterns. Physical Review A 36: 842-848.

26. Hermann J, Stanley HE (1988) The fractal dimension of the minimum path in two and three dimensional percolation. Journal Phys A 21: 829-33.

27. Bianciardi G, Miracco C, De Santi MM, Luzi P (2003) Differential diagnosis between mycosis fungoides and chronic dermatitis by fractal analysis. J Dermatol Sci 33: 184-186. 
Citation: Giorgio Bianciardi, Vincenzo Rizzo, Maria Eugenia Farias, Nicola Cantasano (2015) Microbialites at Gusev Crater, Mars.. Astrobiol

28. Bianciardi G, Tanganelli I, Totangiancaspro D, Brogi M, Carducci A, et al. (2006) Fractal Analysis of monocytes in Diabetes. Clin Hemorheol Microcirc 35: 269-272.

29. Bianciardi G, Traversi C, Cattaneo R, De Felice C, Monaco A, et al. (2012) Phase transition of the Microvascular Network. Architecture in Human Pathologies. Theor Biol Forum 105: 37-45.

30. Bianciardi G, Miracco C, Lazzi S, Luzi P (2013a) Fractal analysis of Epitelial-Connettive Tissue in Basal Cell Carcinoma of the skin. Current Bioinformatics 8: 357-361

31. Bianciardi G, Acampa M, Lamberti I, Sartini S, Servi M, et al. (2013b) Microvascular abnormalities in Rett syndrome. Clin Hemorheol Microcirc 54 109-113.

32. Walter RW (1976) Stromatolites. In Development in sedimentology, 20, Walter, R.M. (Ed.), 1-790. Elseiver Scientific Publishing Company, Amsterdam, The Netherlands.

33. Folk RL (1980) Petrology of Sedimentary Rocks. Hemphill Publishing Company, Austin, Texas, p. 182.

34. Chafetz HS (1986) Marine peloids: A product of bacterially induced precipitation of calcite. Journal of Sedimentary Petrology 56: 812-817.

35. Squyres SW, Arvidson RE, Bell JF, Calef F, Clark BC, et al. (2012) Ancient impact and aqueous processes at Endavour Crater, Mars. Science 336: 570-576.

36. Reid RP, Visscher PT, Decho AW, Stolz JF, Bebout BM, et al. The role of microbes in accretion, lamination and early lithification of modern marine stromatolites. Nature. 2000; vol. 406, 989-992.
37. Grotzinger JP, Beaty D, Dromart G, Gupta S, Harris M, et al. (2011) Mars sedimentary Geology: Key concepts and outstanding questions. Astrobiology 11: 77-87.

38. Rothchild LJ (1990) Earth analogs for martian life: microbes in evaporates, a new model system for life on Mars. Icarus 88: 246-260.

39. Walter MR, Des Marais DJ (1993) Preservation of biological information in thermal spring deposits-developing a strategy for the search for fossil life on Mars. Icarus 101: 129-143.

40. Kerr RA (1997) Putative martian microbes called microscopic artifacts. Science 278, 1706-1707.

41. Vali H, Paquette J, Sears SK, Temmam M, Williams-Jones AE, et al. (1997) Significance of microstructures for the recognition of biological mediated mineralization. Proc SPIE 3111: 137-143.

42. Westal F (1999) The nature of fossil bacteria: a guide to search for extraterrestrial life. J Geophys Res 104: 16437-16451.

43. Boston PJ, Spilde MN, Northup DE, Melim LA, Soroka DS, et al. (2001) Cave biosignature suites: Microbes, minerals and Mars. Astrobiology Journal 1: 25-55.

44. Noffke N (2015) Ancient Sedimentary Structures in the <3.7 Ga Gillespie Lake Member, Mars, that resemble macroscopic morphology, spatial associations, and temporal succession in terrestrial microbialites. Astrobiology 15: 169-192. 